This is an electronic reprint of the original article. This reprint may differ from the original in pagination and typographic detail.

Author(s): Haapanen, Mika; Lenihan, Helena; Tokila, Anu

Title: Innovation Expectations and Patenting in Private and Public R\&D Projects

Year: $\quad 2017$

Version:

Please cite the original version:

Haapanen, M., Lenihan, H., \& Tokila, A. (2017). Innovation Expectations and Patenting in Private and Public R\&D Projects. Growth and Change, 48(4), 744-768. https://doi.org/10.1111/grow.12193

All material supplied via JYX is protected by copyright and other intellectual property rights, and duplication or sale of all or part of any of the repository collections is not permitted, except that material may be duplicated by you for your research use or educational purposes in electronic or print form. You must obtain permission for any other use. Electronic or print copies may not be offered, whether for sale or otherwise to anyone who is not an authorised user. 
Forthcoming in Growth and Change

\title{
Innovation Expectations and Patenting in Private and Public R\&D Projects
}

\author{
MIKA HAAPANEN*, HELENA LENIHAN, AND ANU TOKILA
}

\section{December 2016}

\begin{abstract}
In this paper, we investigate how the innovation expectations of public financiers are related to realized patents. The analysis is based on a novel dataset of collaborative R\&D projects subsidized by the Finnish Agency of Technology and Innovation (Tekes) and the European Regional Development Fund (ERDF) during the period 2000-2004. Innovation expectations are measured using reports submitted by Tekes experts during ex ante assessments of projects. Our probit model results reveal that Tekes' patent expectations are positively related to realized patents for projects led by private firms (but not by public organizations). For large organizations, Tekes' innovation expectations are better at predicting patenting.
\end{abstract}

Keywords: Patenting, innovation expectations, public financiers, R\&D projects

JEL classifications: O38, H25, R58

* Corresponding author.

Mika Haapanen is a senior researcher in Economics at the School of Business and Economics, University of Jyväskylä, Jyväskylä, Finland. His e-mail-address is: mika.p.haapanen@jyu.fi. Helena Lenihan is an associate professor in Economics at the Department of Economics, Kemmy Business School, University of Limerick, Limerick, Ireland. Her e-mail-address is: helena.lenihan@ul.ie. Anu Tokila is a development director at the Jyväskylä Educational Consortium, Jyväskylä, Finland. Her email-address is: anu.tokila@jao.fi. We would like to thank the participants of the PPEGS seminar at the University of Limerick (2012); the ISBE Congress (2012); the meeting of the Finnish Economic Association (2013); and the Pellervo Economic Research seminar (2013) as well as Timo Tohmo, Leena Kerkelä, Justin Doran, and the three anonymous reviewers for helpful comments. We gratefully acknowledge financial support from the Jenny and Antti Wihuri Foundation (2013, project "Public support in regional business finance"). 


\section{Introduction}

The centrality of innovation to local, regional, and national competitiveness (and, in turn, economic growth) has been widely recognized (e.g., Asheim, Smith, and Oughton 2011; Cooke, Uranga, and Etxebarria 1998; Nijkamp, Stough, and de Vaz 2007; Swann 2009). Indeed, the significance of innovation for economic growth has been a core element of growth theory since Schumpeter's (1934) seminal work. Europe 2020, the European Union's growth strategy, aims for smart, sustainable, and inclusive growth; its focus is on developing economies based on knowledge and innovation. As part of this goal, the European Commission has proposed increased research and development (R\&D) investments in accordance with EU targets (European Commission 2010). At the regional level, provinces are encouraged to formulate their research and innovation strategies for smart specialization (RIS3). Notably, patenting is regarded as one of the key indicators for R\&D and innovation in Europe 2020 (Eurostat 2016).

The importance of innovation is widely accepted, but its definition and measurement remains an issue of considerable debate. Innovation is regarded as economically useful new knowledge or technological change (Acs, Anselin, and Varga 2002; Basberg 1987). Measures of innovation are typically based on the analysis of inputs and intermediate outputs or direct measures of innovative outputs. ${ }^{1}$ Direct approaches, especially those based on surveys of innovative companies, are often preferred because they can better reveal the commercial use of new ideas. However, most available methods are indirect. Patents and trademarks are commonly used as intermediate proxies for innovation output (e.g., Artz et al. 2010; Buesa, Heijs, and Baumert 2010; Crosby 2000; Fornahl, Broekel, and Boschma 2011; Galasso and Simcoe 2011; Griliches 1990; Gössling and Rutten 2007; Ho 2009; Yang and Lin 2012).

Prior studies have compared patent and direct innovation output measures. Acs, Anselin, and Varga (2002) compared national patent data and direct innovation output 
indicators in the United States (U.S.). The authors found that those two measures produce very similar results for regional spillover activity; thus, patents provide a fairly reliable measure of innovation activity. This evidence was also supported by Acs and Audretsch (1989). Therefore, examining patent data can provide useful insights regarding the innovation output of R\&D projects, although there are several limitations in the use of patent data, as will be discussed in the next section.

The purpose of this paper is to shed more light on patenting in collaborative $R \& D$ projects. In this analysis, we use a detailed project-level dataset of collaborative R\&D projects subsidized by the Finnish Funding Agency for Technology and Innovation (Tekes) during the period 2000-2004. The dataset contains reports submitted by Tekes experts during an ex ante assessment of the projects. In particular, the Tekes experts provide their expectations about patents, innovations, and new production methods associated with the projects. We merge these data with information on realized patents from the Finnish patent register (PatInfo) to investigate whether the public financiers' ex ante innovation expectations are related to patenting as of the end of June 2012.

This paper contributes to current knowledge of innovation in several ways. First, prior empirical research on public financiers' ex ante expectations is limited. ${ }^{2}$ Although some prior studies have utilized information about policy makers' perceptions or expectations, we are unaware of prior studies focusing on $R \& D$ or innovation activities. Research has, for example, studied urban policy makers' expectations about information and communication technology and modeled the factors affecting such perceptions (Cohen-Blankshtain and Nijkamp 2004; Cohen-Blankshtain, Nijkamp, and van Montfort 2004). Prior research has also considered the determination of deadweight in subsidized business projects, that is, the public sector's expectations of the extent to which projects will be abandoned in the absence of public support (e.g., Lenihan 2004; Tokila, Haapanen, and Ritsilä 2008). Later research has 
utilized these expectations to provide estimates of regional deadweight spending (Tokila and Haapanen 2012). In a related study, Tokila and Haapanen (2009) considered how views of deadweight differ between the firms seeking funding for business projects and the public financiers providing it. ${ }^{3}$ Their findings showed that these two views of project deadweight are highly uncorrelated.

Second, by investigating the link between public financiers' ex ante innovation expectations and realized patents (ex post), our analysis can inform policy makers about whether their expectations carry additional power in predicting patenting from subsidized projects - in addition to the characteristics of the projects (e.g., costs, industry) and their leaders (e.g., size of the organization, prior patenting experience). Our analysis also allows us to investigate which of three expectation variables, that is, expectations for patents, innovations, and new production methods, are useful in this respect. Interpreted more broadly, our study is related to the literature on the effectiveness of public subsidies, although we do not consider the causal effects of subsidies. For example, Zúñiga-Vicente et al. (2014) and Becker (2015) highlighted the increasing level of concern about the effectiveness of public subsidies, reflecting societal demands for the efficient use of public funds. ${ }^{4}$

Third, in this analysis, we are also able to distinguish between collaborative R\&D projects that are led by private firms and those led by public research organizations (PROs). Our probit model results reveal that Tekes' patent expectations are positively related to realized patents for projects led by private firms but not by public organizations. For large organizations, Tekes' innovation expectations are better at predicting patenting. However, expectations of new production methods are not positively related to realized patents.

The remainder of this paper is structured as follows. The second section presents an overview of the related literature on patenting and collaboration in $R \& D$ projects. The third section describes the data and method of empirical analysis. The fourth section presents the 
results and their robustness to alternative specifications of the sample and the dependent variable. The final section discusses the implications of the results and concludes.

\section{Patenting and Collaboration in R\&D Projects}

The current study focuses on Finland, which is a top performer both in R\&D investment and in patent activity (for example, Molle 2007; Tekes 2008, 2012). Finland has been ranked many times as the most innovative nation in the EU (Park and Lee 2005). Innovation policy ${ }^{5}$ in Finland aims to enhance development by harnessing innovation potential across the whole country. The results of innovation activities can be monitored in many ways; Tekes uses patents as one of three tangible measures of innovation activity ${ }^{6}$ at the subsidy-recipient level. In fact, patenting is the only one of those three measures in which a connection with Tekes' activities is demonstrated by national statistics (Tekes 2008, 2012).

During the last two decades, the main trend in innovation policy has been the strengthening of collaboration among industry, government, and research organizations (Santamaría, Barge-Gil, and Modrego 2010). These interrelations are considered important factors for EU competitiveness (Molle 2007). This is supported by the economic theory arguing that these types of interactions are a source of economic growth in a knowledge-based economy (see Leydesdorff and Meyer 2006). Accordingly, the Finnish innovation system is based on the triple helix model, whereby universities, polytechnics, and other PROs and firms (industry) are regarded as the key actors, along with support from government stakeholders, in creating and using new knowledge and innovation. ${ }^{7}$

The link between university and industry is regarded as critical for innovation, and this type of collaboration is therefore recommended by Finnish financiers (Park and Lee 2005). In recent decades, universities in Finland have developed capabilities and guidelines in immaterial property rights (IPR) such as patenting. In 2014, four PROs (three academic universities) were listed among the 15 most active patenting organizations in Finland (Finnish 
Patent and Registration Office 2016). Finnish polytechnics, which take more practical/applied and regional approaches, were gradually established in the 1990s and financially reinforced by the Ministry of Education (OECD 2003). The polytechnics are also actively engaged in R\&D (OECD 2003).

Previous research recognized industrial districts, innovation networks, and innovative milieus as potentially important determinants of innovation activity (Fritsch and Franke 2004). Collaboration generates positive externalities for society as a result of collective learning. As such, cooperative relationships are an important source of spillovers. Thus, public support for cooperation can be defended by Von Hippel's (1988) arguments about the relevance of technological alliances and networks to innovation. Edquist, Eriksson, and Sjögren (2002) also found evidence that collaboration positively affects patent activity because partners can share the costs of patenting. The importance of collaboration for regional knowledge spillovers has also been criticized. For example, Fritsch and Franke (2004) demonstrated that R\&D cooperation plays only a minor role in regional spillovers.

In terms of knowledge diffusion, Lööf and Broström (2008) provided evidence of university collaboration improving innovative performance, including patenting by large manufacturing firms. However, this result was not significant for service companies. Using U.S. data, Bacchiocchi and Montobbio (2009) found that university and public research patents had more knowledge diffusion than private companies' patents in terms of patent citations. However, their evidence for Europe and Japan was not as strong. The quality of patents by universities and research institutes may not be high in terms of their commercial usability. For universities, patenting was found to be beneficial only in some fields, and it may crowd out more traditional university knowledge transfer systems such as publications, conferences, and consulting (Bacchiocchi and Montobbio 2009). Conversely, for Belgium, Van Looy, Callaert, and Debackere (2006) found that involvement in inventive activities does 
not hamper 'pure' scientific activities, at least not in terms of the amount of publications. Rather, engagement in technology development efforts reinforces (i.e., creates positive spillover effects on) scientific performance. Thus, their findings support Owen-Smith's (2003) 'hybrid regime' view of commercial and academic activities, where achievement in one realm is dependent upon success in the other.

With regard to industry, not all companies utilize patent systems. There are significant differences among industries in the propensity to patent. In the pharmaceutical and chemical industries, important inventions are almost always protected (Swann 2009). For example, Mansfield (1986b) found that 80 percent or more of the inventions in the pharmaceutical and chemical industries were protected by patenting. In the primary metals and motor vehicles industries, this percentage was significantly lower. Earlier studies also supported the observation that the pharmaceutical industry regards patents as very important (Mansfield 1986a; Taylor, Silberston, and Silberston 1973). Finnish patenting activity is particularly high in information and communications technology (ICT) but is low in biotechnology, compared to the European average (Statistics Finland 2006).

Regarding company size, patent protection is believed to be more important to smaller firms than to larger ones, whereas larger firms have more capacity for the bureaucracy of patenting processes. However, the relation between firm size and innovation is not straightforward. Large and small firms each have a relative innovative advantage under different circumstances (Acs and Audretsch 1987). Large firms have a relative advantage in capital-intensive and concentrated industries, while small firms have a relative advantage in highly innovative, fragmented and skill-intensive industries. Furthermore, Acs and Audretsch (1988) found that the total number of innovations is negatively related to concentration and unionization in the industry and positively related to firms' R\&D expenditures, skilled labor, and market share. There are also industrial differences in this sense. According to Mansfield 
(1986a), in the pharmaceuticals, chemicals, and petroleum industries, the very large firms were more active in patenting.

Organizations with strong internal research capabilities are able to generate more innovation. Schmookler (1966) previously demonstrated that the size of technology units in terms of number of employees and R\&D expenditures is highly correlated with firms' patenting activity. Later, Bogner and Bansal (2007) and Artz et al. (2010), among others, found a positive relationship between firm-level R\&D spending and patenting. In contrast, Cardinal and Hatfield (2000) observed an insignificant relationship between R\&D spending and patenting: size, measured as the number of employees, was found to be more important for patenting than R\&D spending. There is also evidence of a U-shaped relationship between R\&D spending and innovation activity (e.g., Artz et al. 2010; Audretsch and Acs 1991).

In sum, the prior literature on the determinants of patenting and innovation - including collaboration between the private and public sectors - is extensive, but it remains unknown, for example, whether public financiers' ex ante expectations are related to realized patents. Thus, in this study, we are particularly interested in whether ex ante patent expectations are related to realized patenting. A positive relationship between patent expectations and realized patenting would provide information on the ability of public financiers to predict patenting of subsidized innovation projects. However, an insignificant relationship does not necessarily imply that subsidies are allocated inefficiently, since public financiers may have other motives for subsidization, besides expected patenting (e.g., inventions and innovations more generally and/or new production methods). Nevertheless, we expect innovation expectations to be positively related to patenting because greater innovation expectations are likely to lead to larger $R \& D$ subsidies and thus research expenditures ${ }^{8}$, which is likely increase the likelihood of patenting (Czarnitzki, Kraft, and Thorwarth 2009). Conversely, having expectations of new production methods may signal that patenting is not the desired outcome 
of a project. Therefore, expectations of new production methods can even be negatively related to realized patenting.

Finally, patents have been criticized for not measuring the economic value of new technologies (Hall, Jaffe, and Trajtenberg 2002). Some patents reflect productive inventions, while other patents are unlikely to be commercialized and to increase productivity. A widely known problem is also that many inventions are never patented (Moser 2013). It has been estimated that, at maximum, half of important inventions are patented (Basberg 1987). In addition, a high patent count need not imply a high level of innovation, as some patents may never be implemented (Becker 2015). Tracking patenting is often biased because companies may patent under the names of their subsidiaries and even in other countries. Patents also have a clear bias toward science and technology and are thus a restricted lens through which to examine innovation. However, patents are more likely to be related to real innovation outputs than, for example, R\&D input data (Crosby 2000). As mentioned in the introduction, patent data and direct innovation output indicators have been found to produce very similar results in regional spillover activity (Acs and Audretsch 1989; Acs, Anselin, and Varga 2002). Hence, we argue that patents can provide useful information about innovation activity as long as their limitations are recognized. ${ }^{9}$

\section{Data and Modeling Framework}

The empirical analysis utilizes information on all 410 collaborative R\&D projects that received European Regional Development Fund (ERDF) funding from the Finnish Funding Agency for Technology and Innovation (Tekes) between January 2000 and May 2004. Our core dataset is based on an official registry compiled by the Ministry of Trade and Industry. In total, 67.4 million euros were spent on these subsidies during this period (on average, 164,507 euros per project). Approximately half of the subsidies came from national sources and half from the ERDF. The main objective of the ERDF subsidies is to increase the long-term 
competitiveness of the European regions. Tekes operates in technology units within the 14 regional Employment and Economic Development (EED) Centres.

The subsidized projects are all collaborative in nature (taking place between private firms and public research organizations). Of the funded projects, 151 (37.8\%) are led by private firms and $259(62.2 \%)$ are led by public organizations. ${ }^{10}$ The supported public organizations are most often university departments $(62 \%)$ or polytechnic departments, including local development agencies (31\%), but the data also include some projects that are led by independent research centers $(7 \%)$.

Tekes reviews project applicants during several phases (cf. Tanayama 2007). First, before the decision-making process begins, it is recommended that applicants have a general discussion with the regional Tekes experts concerning program objectives and the innovation potential of a project proposal. Following this initial discussion, and after the applicant has submitted an electronic application, Tekes forms a project team to assess the proposal. The team is assembled from the relevant technology field to ensure that it has the best technology and industry knowledge related to the proposal. The third stage involves an assessment meeting with the applicant where several indicators are presented. Based on this meeting, the leader of the Tekes project team makes a preliminary proposal about the financing decision and Tekes' ex ante expectations for the project, including expected patents, innovations, and new production methods. Among the Tekes' subsidy criteria, the role of innovation expectations is discretionary and is used in combination with other desired indicators. For example, the economic potential is estimated in terms of new firms, new jobs, and increased value of turnover and exports. The final decisions are determined in the financial meeting, which includes all the financing experts and directors representing the highest authority of the regional office. 
To provide empirical information on the support mechanism, we have examined how project-level innovation expectations are related to the intensity of assistance (i.e., the ratio of the subsidy to the project cost). The results of simple regression models are reported in the Appendix (see Table A1). They show that patent expectations have a positive relationship with the intensity of assistance after controlling for several project-level and organizationlevel factors. Thus, projects for which the public financiers have patenting expectations are more intensely supported. Although this finding is consistent with the view that patent expectations are used as one subsidy criterion, it does not necessarily mean that patenting is an important criterion for all projects, for example, because patent expectations are zero for many projects.

Patent applications in Finland are directed to, and granted by, the Finnish Patent and Registration Office (PRH). Applications are examined using advanced tools and databases. To be accepted, an invention must be new, involve an inventive step and be industrially applicable. It is clearly stated that scientific theories, aesthetic creations, mathematical methods and programs for computers are not regarded as patentable inventions (Finnish Patent and Registration Office 2015). Many patent applications are rejected. For example, $33 \%$ of Finnish patent applications between 2000 and 2005 were not granted patents because they lacked novelty; that is, the patent application was filed for an already published invention (Loikkanen et al. 2009).

The main purpose of the empirical analysis is to investigate how Tekes experts' expectations predict realized patents after controlling for other factors. To construct an ex post measure of innovation output that occurs after funding has been granted, we utilized the official Finnish patent register (PatInfo). The PatInfo database is maintained by the PRH and contains basic data, procedural status, validity, and payment information on all Finnish patent applications filed since 1979. Using the PatInfo database, we searched for information on 
whether patents were granted to the lead organization of project $i$. Patent activity is measured from the date that project funding was granted until the end of June 2012; this observation period is, on average, approximately ten years. ${ }^{11}$ We then constructed a dichotomous dependent variable, realized patenting, $y_{i}$, that takes a value of 0 if no patent has been granted and 1 if a patent has been received. Approximately 27 percent of the lead organizations had received a patent by this date. ${ }^{12}$

Central to this study is the information on Tekes' ex ante estimate of the innovation potential of each project. The Tekes experts report their expectations regarding patenting, innovations, and new production methods for each project. We utilize these perception measures as dichotomous independent variables. For example, patenting expectations is equal to 1 if at least one patent is expected from a project and 0 if no patents are expected. Variables describing the innovation expectations and new production method expectations are defined accordingly. These latter expectations refer to a new or improved product or service or a new production method that is a significant improvement from the earlier one (cf. Tekes 2003). The innovations are new products or services that are brought to the marketplace or new production methods implemented by the company. Unfortunately, we have no data on the actual innovations or new production methods developed by the assisted organizations that could be merged (such as the Community Innovation Survey). Therefore, we cannot study how innovation expectations and new production method expectations are related to their realized outcomes. Instead, these expectations are only utilized as additional explanatory variables in the patenting model below.

To model the link between these ex ante expectations and realized patents, we utilize a probit model (see, for example, Greene 2008). That is, we assume that realized patenting, $y_{i}$, is determined according to a latent variable $y_{i}^{*}$ :

$$
y_{i}^{*}=\alpha^{\prime} z_{i}+\beta^{\prime} x_{i}+\varepsilon_{i}, \quad \varepsilon_{i}=N(0,1)
$$




$$
y_{i}=1 \text { if } y_{i}^{*}>0 \text {, and } y_{i}=0 \text { if } y_{i}^{*} \leq 0 \text {, }
$$

where $z_{i}$ contains the key explanatory variables of interest describing the innovation expectations of the Tekes experts and $x_{i}$ contains control variables. $\alpha$ and $\beta$ are estimated parameter vectors and $\varepsilon_{i}$ are standard normal distributed error terms (see Table A2 in the Appendix for the definitions of the variables).

We use several control variables at the project and organization levels (cf. discussion in the previous section). These variables are measured at the time the subsidy was granted. Beginning with project-level factors, project costs are included because larger R\&D projects are more likely to lead to a patent, ceteris paribus. For public-led projects, the intensity of assistance is $50-100 \%$ of the accepted project costs (the average is $85 \%$ ). The intensity of assistance is lower for projects led by private firms (the average is $49 \%$ ). We also utilize Tekes' estimate of the project's deadweight: Zero deadweight takes a value of 1 if Tekes estimates that the project would be abandoned in the absence of a subsidy and 0 otherwise. This variable may also proxy for the project risks. On the one hand, higher risk entails higher failure rates (which relate negatively to patenting); but on the other hand, higher risk also entails a higher chance of novel inventions (which relates positively to patenting).

Our data include projects from different industries: many projects aim to produce innovations in metal and technology (20\%), forestry, wood, and bio (19\%), information and communication technology (16\%) and the pharmaceutical industry (6\%); meanwhile, some projects develop the operating environment for business networks $(18 \%)$. The differences between industries are also likely to be reflected in the public financiers' innovation expectations. As discussed above, the importance of patenting (and innovations) is also likely to vary substantially across the industries. Thus, the projects are categorized into six groups according to their industry type (e.g., ICT, forestry, and metal) to control for any heterogeneity in the likelihood of patenting across industries. 
Characteristics of the lead organization include its size (in terms of number of employees) and ownership (private or public). The firm size and project costs together proxy for the scale differences of the lead organization's R\&D expenditures (cf. literature on patent production functions, e.g., Hall, Griliches, and Hausman 1983). For the private firms, we control for their turnover (euros); and for the PROs, we control for the type of organization (university, polytechnic, research centreer). The model also includes a dummy variable that takes a value of 1 if the lead organization has previously been granted a patent and 0 otherwise. The data include observations from five consecutive years. Thus, we employ dichotomous variables for the four-year period (2001-2004) that capture cyclical changes in patenting and an index for the length of the observation period. In addition, four dichotomous variables utilizing the NUTS 2 regional classification are incorporated to control for differences in innovation activity among Southern, Western, Eastern, and Northern Finland.

Note that the key independent variables are measured for the subsidized project, but the dependent variable is measured for the lead organization as a whole. ${ }^{13}$ Subsidization of one project may generate spillover effects on other innovation projects inside an organization. An advantage of our setting is that to some extent, it can capture the additional (long-run) benefits from subsidized R\&D investments at the organizational level. The main disadvantage is that large organizations in particular can be engaged in other R\&D activities unrelated to the project investigated here that can also generate patents. We will further consider the importance of this limitation below when we report our robustness checks. Finally, because the patent data are based on the national patent registry, export firms in particular may have filed priority applications directly with the European Patent Office (EPO). However, such an event is rare; having researched every project to determine whether the project leaders involved had applied for or received patents from the EPO, we found that no project leader without a patent from the Finnish patent office had received one from the EPO. 


\section{Results}

Descriptive results. Table 1 shows the mean values of the project expectation variables. They are reported based on realized patenting (yes/no) together with two-sample ttests that test the differences in the means. Tekes expected patents from $12 \%$ of the projects led by organizations that later received patents. The corresponding figure is slightly smaller (9\%) for those that did not receive patents, but the t-test does not indicate a significant difference between the means. Instead, projects leading to patents were significantly more likely to have positive innovation expectations (45\% vs. 29\%). Regarding expectations of new production methods, the results of the t-test show no significant difference between the means.

We have also calculated simple Pearson's correlation coefficients between the three expectation variables. They indicate that patent expectations are less correlated with innovation expectations $(0.47 ; \mathrm{p}<0.01)$ and new production method expectations $(0.41 ; \mathrm{p}<$ 0.01) than innovation expectations and new production method expectations are with each other $(0.73 ; \mathrm{p}<0.01)$. Thus, the latter two variables provide additional variation that can be exploited in the analysis of patenting behavior, even though the correlations are significant (and sizable).

TABle 1. Mean VAlues by ObSERVEd Patenting.

\begin{tabular}{lccc}
\hline & \multicolumn{3}{c}{ Realized patenting $\left(y_{i}\right)$} \\
\cline { 2 - 4 } $\begin{array}{l}\text { Tekes experts' innovation } \\
\text { expectations }\end{array}$ & $\begin{array}{c}\text { No patent } \\
\text { received }\end{array}$ & $\begin{array}{c}\text { At least one patent } \\
\text { received }\end{array}$ & $\begin{array}{c}\text { Difference } \\
\text { in means }\end{array}$ \\
\hline Patent expectations & 0.093 & 0.119 & 0.026 \\
Innovation expectations & 0.289 & 0.450 & $0.161^{* * *}$ \\
New production method & 0.355 & 0.394 & 0.039 \\
$\quad$ expectations & 301 & 109 & 410 \\
\hline Number of observations & & & .
\end{tabular}

Notes: *** Two-sample t-test indicates significant differences in means with $\mathrm{p}<0.01$. Other differences in means are not significantly different from zero $(p>0.10)$. 
Table 2 shows the mean values of the explanatory variables utilized. The first column lists them for the full sample, and the second and third columns list them for the subsample of projects led by private firms and by public organizations. Only $10 \%$ of the subsidized projects are expected to generate patents (column 1), but innovations (33\%) and new production methods $(37 \%)$ are expected more often. ${ }^{14}$ The final column reports considerable differences in the means between the two subsamples (private vs. public) together with t-tests. The likelihood of having expectations for patenting $(\mathrm{p}<0.1)$ and new production methods $(\mathrm{p}<$ 0.01) is significantly lower for public-led projects than private-led projects. On the one hand, it is surprising that $\mathrm{R} \& \mathrm{D}$ funding has been given to these projects even though the public financiers do not have positive innovation expectations for them. On the other hand, several other criteria are used for subsidization. For example, in approximately $26 \%$ of the projects, the criteria for subsidization were stated to improve the level of production instead of the quality of the products (74\%). Moreover, Tekes (2003) regards product, process, or service as an innovation when it meets the above novelty criteria from the perspective of the innovating company; thus, it does not need to be a new innovation for other companies or in the market generally. Hence, projects can be subsidized even though they are not expected to lead to novelty in the market.

There are also noticeable differences in the values of the control variables between the private-led projects and the public-led projects. For example, the project costs are significantly lower and the intensity of assistance is significantly higher for the subsidized public-led projects. Moreover, deadweight is more often expected to be zero in public-led projects than in private-led projects; that is, Tekes' expectation is that, more often, the publicled projects would not be implemented without the subsidy. The public leaders are, on average, larger in size than the private leaders. Given these substantial differences across the 
subsamples, we estimate the probit models separately for the private-led projects and the public-led projects.

TABLE 2. MEAN VALUES OF EXPLANATORY VARIABLES By SAMPLE.

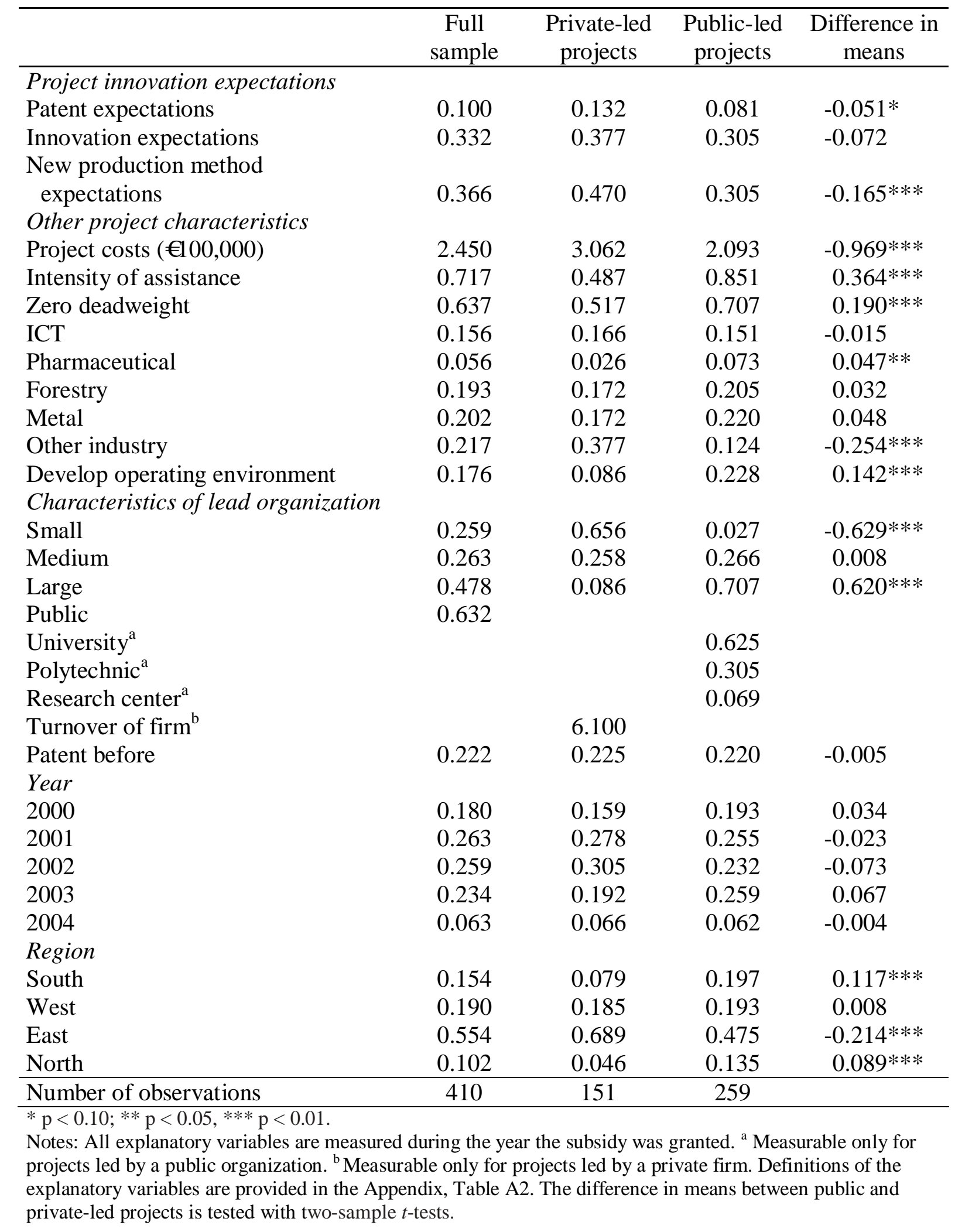


Modeling results. Table 3 displays the estimated average marginal effects on patenting. ${ }^{15}$ A marginal effect is first calculated for each observation with its observed characteristics. These effects are then averaged across all observations. The first column is for the full sample. ${ }^{16}$ Then, the second and third columns are for the subsamples of projects led by private firms and by public organizations, respectively. For brevity, the discussion focuses on the latter two results.

Note, however, that we do not find any significant relationship between patent expectations and realized patenting in the full sample, even after controlling for other factors (column 1). This finding is consistent with the descriptive analysis presented in Table 1: only innovation expectations correlate positively with patenting in the follow-up period. Conversely, projects that have positive expectations for new production methods are less likely to lead to patents. It could be that the new production methods are novel but patenting is a less popular protection mechanism for these process innovations than product innovations; see Cohen, Nelson, and Walsh (2000) for early survey evidence. Thus, having positive expectations for new production methods may signal that patenting was not the desired outcome of the project. An alternative explanation could be that the new production methods are not novel in the market but are novel to the project members or more widely in the region. ${ }^{17}$ 
Table 3. Average Marginal EfFects on Patenting by Sample.

\begin{tabular}{|c|c|c|c|c|c|c|}
\hline \multirow{2}{*}{$\begin{array}{l}\text { Variable } \\
\text { Project innovation } \\
\text { expectations }\end{array}$} & \multicolumn{2}{|c|}{ (1) Full sample } & \multicolumn{2}{|c|}{$\begin{array}{l}\text { (2) Private-led } \\
\text { projects }\end{array}$} & \multicolumn{2}{|c|}{$\begin{array}{l}\text { (3) Public-led } \\
\text { projects }\end{array}$} \\
\hline & & & & & & \\
\hline Patent expectations & -0.012 & $(0.071)$ & $0.077 *$ & $(0.041)$ & -0.062 & $(0.082)$ \\
\hline Innovation expectations & $0.245 * * *$ & $(0.093)$ & $0.114^{*}$ & $(0.061)$ & $0.214 * *$ & $(0.102)$ \\
\hline $\begin{array}{l}\text { New production method } \\
\text { expectations }\end{array}$ & $-0.136 * *$ & $(0.064)$ & $-0.152 * * *$ & $(0.039)$ & -0.149 & $(0.123)$ \\
\hline $\begin{array}{l}\text { Other project } \\
\text { characteristics }\end{array}$ & & & & & & \\
\hline $\ln$ (Project costs) & -0.020 & $(0.023)$ & -0.021 & $(0.023)$ & -0.047 & $(0.035)$ \\
\hline Intensity of assistance & -0.227 & $(0.216)$ & $0.901 * * *$ & $(0.346)$ & $-0.491 * *$ & $(0.224)$ \\
\hline Zero deadweight & -0.049 & $(0.055)$ & 0.032 & $(0.057)$ & $-0.092 *$ & $(0.048)$ \\
\hline Pharmaceutical & -0.137 & $(0.088)$ & 0.033 & $(0.105)$ & -0.273 & $(0.185)$ \\
\hline Forestry & $0.201 * *$ & $(0.082)$ & 0.004 & $(0.031)$ & $0.267 * * *$ & $(0.098)$ \\
\hline Metal & $0.104 *$ & $(0.056)$ & $-0.193 * * *$ & $(0.066)$ & $0.227 * * *$ & $(0.074)$ \\
\hline Other industry & 0.044 & $(0.063)$ & -0.000 & $(0.067)$ & 0.083 & $(0.098)$ \\
\hline $\begin{array}{l}\text { Develop operating } \\
\text { environment }\end{array}$ & -0.041 & $(0.067)$ & 0.016 & $(0.121)$ & -0.056 & $(0.075)$ \\
\hline $\begin{array}{l}\text { Characteristics of lead } \\
\text { organization }\end{array}$ & & & & & & \\
\hline Medium $^{\mathrm{a}}$ & $0.187 * * *$ & $(0.046)$ & $0.162 * * *$ & $(0.038)$ & & \\
\hline $\operatorname{Large}^{\mathrm{a}}$ & $0.146 * *$ & $(0.072)$ & $0.210 * *$ & $(0.106)$ & -0.011 & $(0.083)$ \\
\hline Public & 0.129 & $(0.134)$ & & & & \\
\hline Polytechnic $^{b}$ & & & & & $-0.186^{*}$ & $(0.104)$ \\
\hline Research center $^{\mathrm{b}}$ & & & & & 0.023 & $(0.129)$ \\
\hline Turnover of firm & & & -0.001 & $(0.002)$ & & \\
\hline Patent before & 0.127 & $(0.086)$ & $0.314 * * *$ & $(0.043)$ & -0.123 & $(0.107)$ \\
\hline Year dummies ${ }^{\mathrm{c}}$ & & & & & & \\
\hline 2001 & 0.016 & $(0.063)$ & $0.115 * * *$ & $(0.035)$ & 0.012 & $(0.083)$ \\
\hline 2002 & -0.072 & $(0.086)$ & $0.163 * *$ & $(0.071)$ & -0.062 & $(0.073)$ \\
\hline 2003 & $-0.177 * * *$ & $(0.068)$ & 0.047 & $(0.054)$ & $-0.202 * *$ & $(0.080)$ \\
\hline 2004 & -0.096 & $(0.104)$ & 0.039 & $(0.086)$ & -0.093 & $(0.118)$ \\
\hline Regional dummies $^{\mathrm{d}}$ & & & & & & \\
\hline West & $-0.419 * *$ & $(0.165)$ & $-0.190 *$ & $(0.098)$ & $-0.352 * * *$ & $(0.115)$ \\
\hline East & $-0.409 * *$ & $(0.164)$ & & & & \\
\hline North & $-0.429 * *$ & $(0.172)$ & & & & \\
\hline East or North & & & 0.072 & $(0.084)$ & $-0.416 * * *$ & $(0.088)$ \\
\hline
\end{tabular}

Number of observations

Notes: The average marginal effects from the probit models are computed as an average over all observations; see Cameron and Trivedi (2005, p. 467). Models also include a constant term. ${ }^{a}$ Reference size is small in columns (1) and (2) and medium in column (3). ${ }^{\mathrm{b}}$ Reference is university-led projects. ${ }^{\mathrm{c}}$ Reference year is 2000.

${ }^{\mathrm{d}}$ Reference region is Southern Finland. 
For projects led by private firms, the results show a positive relationship between Tekes' patent expectations and the realized patenting of the lead organization, ceteris paribus (column 2). The estimated marginal effect is 0.08 , which implies that if a project led by a private firm is expected to lead to patents, then the likelihood of a patent increases, on average, by 8 percentage points. Having innovation expectations is also positively related to realized patenting. The estimated average marginal effect is 11 percentage points. Due to the weak precision of the estimates $(\mathrm{p}<0.1)$, this three-percentage-point difference in marginal effects is not significant. In contrast, having positive expectations for new production methods is negatively related to realized patenting, as in the full sample. The estimated marginal effect implies that if a private-led project is expected to lead to new production methods, then the likelihood of a patent decreases by 15 percentage points. For the public-led projects, having innovation expectations is again positively related to realized patenting (marg. eff. is 0.21 ), but patent expectations are not significantly related to patenting (column 3). As before, the relationship between expectations for new production methods and realized patenting is negative, and size of the estimate is similar to that reported for private-led projects, although the estimate is not significant.

Regarding the control variables, public-led projects in the forestry, wood, and bio industry and the metal industry show a higher likelihood of producing patents relative to the other industries. The industry differences are smaller for the private-led projects. Contrary to our expectations, patenting in pharmaceutical projects is not particularly common. However, only a small number of projects have been subsidized, and they may differ from typical projects in the industry. Intensity of assistance is positively related to patenting for the private-led projects but negatively related for public-led projects. Given that we have also found a positive relationship between having patent expectations and the intensity of assistance, the allocation of subsidies may not have been as desired by the public financiers if 
they wanted patents from these projects. Further research is needed in this respect. For publicled projects, Tekes' estimate of zero deadweight (and possibly financial risks) is weakly negatively related to the likelihood of receiving patents.

Medium- and large-sized private organizations are more likely to be granted patents than small organizations. However, we do not find significant differences in patenting by size for public-led projects, perhaps partly because most public organizations are large. Of the public-led projects, those led by universities are more likely to lead to a patent than projects led by polytechnics (significant at the $10 \%$ level). Thus, our results suggest that being engaged in academic research (at a university) compared to more practical/applied and regionally demanded research (at a polytechnic) is associated with an increased likelihood of patenting (cf. Van Looy, Callaert, and Debackere 2006). For the private-led projects, prior patenting has a significant positive effect on future patenting, as expected. However, for the public-led projects, this effect is insignificant. This result is logical because the importance of patenting has emerged within the PROs only recently, as explained above. The results also show that project leaders from Southern Finland, where economic growth rates are highest, are particularly likely to patent. Finally, year dummies indicate some cohort differences in patenting, but the pattern differs by subsample.

Additional analyses. We measure realized patenting at the organizational level and expectations at the project level, which can be particularly problematic for large organizations because they are likely to engage in other $R \& D$ unrelated to the project investigated here that can also generate patents. To mitigate this problem, we have excluded large organizations with at least 250 employees in the first robustness check (Table 4). The results show, as before, that Tekes' expectations of new production methods are negatively related to patenting, but some changes are noticeable in the other expectation variables. For the privateled projects (column 2), the relationship between patent expectations and realized patenting is 
now stronger than in the full sample, but the relationship between innovation expectations and realized patenting is weaker. Unexpectedly, patent expectations are negatively related to the realized patenting of the subsidized public organizations (column 3). This observation hints that Tekes' patent expectations toward the public-led projects may be based on expectations that some of the private partners are patenting instead of the leader. We will investigate this possibility next.

Our primary measure of realized patenting only concerns the lead organizations. Because the projects investigated here are collaborative, Tekes' assessment involves the project as a whole, and the project may generate additional patents for non-lead partners. Therefore, we have collected information on the patenting activity of the project partners. The names of the partners are known for a subsample $(38.5 \%)$ of projects that are led by PROs. Using this information, we have defined a new dependent variable that takes a value of 1 if any of the partners have received more patents during a ten-year follow-up period than before subsidization of the project and 0 otherwise. Average marginal effects are reported in column (1) of Table 5. This second robustness check shows, as in column (3) of Table 3, that the innovation expectations of the projects are positively related to the patenting of the partners, and the relationships for the other expectation variables are not significant. Thus, the (unexpected) negative relationship between patent expectations and realized patenting observed in column (3) of Table 4 is no longer significant for public-led projects. However, because the partner information is known for only a small proportion of the projects, it is unknown whether this finding generalizes to all public-led projects in the data.

As a third robustness check, we consider the possibility that lead organizations have applied for patents but have not necessarily received them, which is a weaker signal of realized innovation actions. Columns (2) and (3) of Table 5 display the average marginal effects on applying for a patent within a five-year follow-up period after receiving a subsidy. 
The results show that having innovation expectations is positively related to the likelihood of applying for a patent in both samples. The results for the other expected project characteristics are also qualitatively similar to those reported in Table 3.

TABle 4. AVERAge MARginAl EfFeCts On PATENTING: EXCluding LARGE ORGANIZATIONS AS PROJECT LEADERS.

\begin{tabular}{|c|c|c|c|c|c|c|}
\hline \multirow{2}{*}{$\begin{array}{l}\text { Variable } \\
\begin{array}{c}\text { Project innovation } \\
\text { expectations }\end{array}\end{array}$} & \multicolumn{2}{|c|}{$\begin{array}{l}\text { (1) Full sample, } \\
\text { excl. large }\end{array}$} & \multicolumn{2}{|c|}{$\begin{array}{l}\text { (2) Private-led } \\
\text { projects, excl. large }\end{array}$} & \multicolumn{2}{|c|}{$\begin{array}{l}\text { (3) Public-led } \\
\text { projects, excl. large }\end{array}$} \\
\hline & & & & & & \\
\hline Patent expectations & 0.056 & $(0.062)$ & $0.101 * * *$ & $(0.028)$ & $-0.530 * *$ & $(0.222)$ \\
\hline Innovation expectations & $0.196 * *$ & $(0.093)$ & 0.035 & $(0.049)$ & 0.099 & $(0.086)$ \\
\hline $\begin{array}{l}\text { New production method } \\
\text { expectations }\end{array}$ & $-0.157 * *$ & $(0.064)$ & $-0.105 * * *$ & $(0.038)$ & $-0.284 * *$ & $(0.141)$ \\
\hline $\begin{array}{l}\text { Other project } \\
\text { characteristics }\end{array}$ & & & & & & \\
\hline $\ln ($ Project costs $)$ & -0.010 & $(0.032)$ & -0.024 & $(0.024)$ & $0.165 * *$ & $(0.066)$ \\
\hline Intensity of assistance & 0.211 & $(0.221)$ & $0.892 * * *$ & $(0.295)$ & $-0.569 * *$ & $(0.266)$ \\
\hline Zero deadweight & 0.029 & $(0.057)$ & 0.048 & $(0.060)$ & 0.144 & $(0.107)$ \\
\hline Pharmaceutical & 0.037 & $(0.094)$ & 0.102 & $(0.077)$ & & \\
\hline Forestry & $0.202 * * *$ & $(0.052)$ & $0.098 * * *$ & $(0.028)$ & $0.691 * * *$ & $(0.145)$ \\
\hline Metal & $0.099 * *$ & $(0.048)$ & $-0.086^{* *}$ & $(0.034)$ & $0.690 * * *$ & $(0.215)$ \\
\hline Other industry & $0.155 * * *$ & $(0.060)$ & $0.084 * * *$ & $(0.025)$ & $0.467 * * *$ & $(0.133)$ \\
\hline $\begin{array}{l}\text { Develop operating } \\
\text { environment }\end{array}$ & $0.147 * * *$ & $(0.056)$ & 0.098 & $(0.093)$ & 0.121 & $(0.075)$ \\
\hline $\begin{array}{l}\text { Characteristics of lead } \\
\text { organization }\end{array}$ & & & & & & \\
\hline Medium & $0.173 * * *$ & $(0.048)$ & $0.182 * * *$ & $(0.059)$ & & \\
\hline Public & 0.033 & $(0.139)$ & & & & \\
\hline Polytechnic & & & & & $-0.691 * * *$ & $(0.107)$ \\
\hline Research center & & & & & 0.154 & $(0.183)$ \\
\hline Turnover of firm & & & -0.005 & $(0.006)$ & & \\
\hline Patent before & $0.265 * * *$ & $(0.096)$ & $0.326 * * *$ & $(0.050)$ & $-0.656 * * *$ & $(0.136)$ \\
\hline Year dummies & & & & & & \\
\hline 2001 & $0.085^{*}$ & $(0.052)$ & $0.198 * * *$ & $(0.062)$ & -0.006 & $(0.099)$ \\
\hline 2002 & -0.002 & $(0.111)$ & $0.251 * * *$ & $(0.047)$ & -0.050 & $(0.056)$ \\
\hline 2003 & -0.066 & $(0.102)$ & $0.139 * *$ & $(0.055)$ & $0.193 * *$ & $(0.098)$ \\
\hline 2004 & -0.049 & $(0.126)$ & $0.155^{* *}$ & $(0.068)$ & 0.039 & $(0.167)$ \\
\hline Regional dummies & & & & & & \\
\hline West & $-0.392 * * *$ & $(0.107)$ & $-0.308 * * *$ & $(0.079)$ & $-0.928 * * *$ & $(0.199)$ \\
\hline East or North & $-0.315 * * *$ & $(0.095)$ & -0.041 & $(0.088)$ & $-0.870 * * *$ & $(0.206)$ \\
\hline Number of observations & 214 & & 138 & & 76 & \\
\hline
\end{tabular}


TABle 5. Average Marginal EfFects on Alternative DePEndent Variables.

\begin{tabular}{|c|c|c|c|c|c|c|}
\hline \multirow{2}{*}{$\begin{array}{l}\text { Variable } \\
\begin{array}{l}\text { Project innovation } \\
\text { expectations }\end{array}\end{array}$} & \multicolumn{2}{|c|}{$\begin{array}{l}\text { (1) Public-led } \\
\text { projects: partners } \\
\text { are patenting }\end{array}$} & \multicolumn{2}{|c|}{$\begin{array}{c}\text { (2) Private-led } \\
\text { projects: applied for } \\
\text { a patent }\end{array}$} & \multicolumn{2}{|c|}{$\begin{array}{l}\text { (3) Public-led } \\
\text { projects: applied } \\
\text { for a patent }\end{array}$} \\
\hline & & & & & & \\
\hline Patent expectations & -0.124 & $(0.100)$ & 0.051 & $(0.039)$ & -0.171 & $(0.117)$ \\
\hline Innovation expectations & $0.231 * * *$ & $(0.069)$ & $0.161 * * *$ & $(0.058)$ & $0.244 * *$ & $(0.101)$ \\
\hline $\begin{array}{l}\text { New production method } \\
\text { expectations }\end{array}$ & -0.042 & $(0.097)$ & $-0.191 * * *$ & $(0.052)$ & -0.154 & $(0.126)$ \\
\hline \multicolumn{7}{|l|}{$\begin{array}{l}\text { Other project } \\
\quad \text { characteristics }\end{array}$} \\
\hline $\ln ($ Project costs $)$ & 0.128 & $(0.082)$ & -0.032 & $(0.027)$ & -0.027 & $(0.034)$ \\
\hline Intensity of assistance & $-0.751 *$ & $(0.414)$ & $0.874 * * *$ & $(0.222)$ & $-0.496 * *$ & $(0.205)$ \\
\hline Zero deadweight & 0.002 & $(0.099)$ & -0.006 & $(0.032)$ & -0.077 & $(0.051)$ \\
\hline Pharmaceutical & $\mathrm{a}$ & & 0.023 & $(0.113)$ & & \\
\hline Forestry & 0.205 & $(0.130)$ & -0.067 & $(0.081)$ & $0.257 * *$ & $(0.113)$ \\
\hline Metal & 0.131 & $(0.135)$ & $-0.181 * *$ & $(0.073)$ & $0.218 * * *$ & $(0.066)$ \\
\hline Other industry & -0.053 & $(0.163)$ & -0.016 & $(0.083)$ & -0.012 & $(0.091)$ \\
\hline $\begin{array}{l}\text { Develop operating } \\
\text { environment }\end{array}$ & -0.145 & $(0.130)$ & a & & -0.080 & $(0.076)$ \\
\hline \multicolumn{7}{|l|}{$\begin{array}{l}\text { Characteristic of lead } \\
\text { organization }\end{array}$} \\
\hline Medium & & & $0.180 * * *$ & $(0.039)$ & & \\
\hline Large & 0.136 & $(0.117)$ & $0.251 * *$ & $(0.102)$ & 0.037 & $(0.097)$ \\
\hline Polytechnic & $-0.396 * * *$ & $(0.110)$ & & & $-0.216^{*}$ & $(0.116)$ \\
\hline Research center & $-0.202 *$ & $(0.121)$ & & & 0.065 & $(0.113)$ \\
\hline Turnover of firm & & & -0.002 & $(0.002)$ & & \\
\hline Patent before & -0.034 & $(0.092)$ & $0.313 * * *$ & $(0.047)$ & -0.105 & $(0.122)$ \\
\hline \multicolumn{7}{|l|}{ Year dummies } \\
\hline 2001 & -0.000 & $(0.074)$ & $0.096 * * *$ & $(0.037)$ & 0.020 & $(0.083)$ \\
\hline 2002 & -0.060 & $(0.085)$ & $0.139 * *$ & $(0.066)$ & -0.073 & $(0.066)$ \\
\hline 2003 & -0.059 & $(0.159)$ & 0.092 & $(0.066)$ & $-0.221 * *$ & $(0.087)$ \\
\hline 2004 & 0.193 & $(0.212)$ & 0.055 & $(0.075)$ & -0.118 & $(0.119)$ \\
\hline \multicolumn{7}{|l|}{ Regional dummies } \\
\hline West & 0.089 & $(0.122)$ & $-0.167 * *$ & $(0.076)$ & $-0.235 * *$ & $(0.101)$ \\
\hline East or North & $0.305 * * *$ & $(0.102)$ & 0.073 & $(0.077)$ & $-0.304 * * *$ & $(0.094)$ \\
\hline Number of observations & 97 & & 151 & & 25 & \\
\hline \multicolumn{7}{|c|}{$* p<0.10 ; * * p<0.05, * * * p<0.01$} \\
\hline $\begin{array}{l}\text { Notes: The average marginal } \\
\text { observations; see Cameron and } \\
\text { the dependent variable is } 1 \text { if a } \\
\text { before it and } 0 \text { otherwise. In co }\end{array}$ & 年 & (2) & 4 & ts in a 10 & ge over all & $\begin{array}{l}\text { Imn (1), } \\
\text { period than } \\
\text { plied for }\end{array}$ \\
\hline
\end{tabular}




\section{Discussion and Conclusions}

This paper has provided new evidence regarding public financiers' expectations of subsidized R\&D projects between public research organizations (PROs) and industry. For Finland, we have investigated the link between Tekes' innovation expectations and patenting ex post. Our descriptive analysis showed that projects that lead to patents are significantly more likely to have positive innovation expectations. Probit models were estimated to reveal whether the public financiers' expectations carry additional power in predicting patenting beyond the standard determinants. Our results showed that Tekes' patent expectations are positively related to patenting for projects led by private firms (but not by PROs) when we focus on small and medium-sized organizations. For large organizations, innovation expectations are better at predicting patenting. Expectations of new production methods are not positively related to patenting; instead, most of our results indicate the opposite.

Taken together, these results suggest that the measurement of public financiers' expectations can provide useful information that can be used in predicting patenting, in addition to the characteristics of the project and its leader. However, in utilizing information about expectations, we need to be aware that public-led and private-led projects differ, and that Tekes' expectations of their patenting activities also differ. For example, for projects led by small and medium-sized firms, patent expectations are good predictors of patenting ex post, however, in most other cases, innovation expectations are better than patenting expectations at predicting patenting. Noting that patenting is a relatively new function, especially in universities and polytechnics, it is not surprising that public financiers do not know their capabilities and thus, their patenting is more difficult to predict.

This paper has provided new evidence for national and EU-level policy makers who design subsidy programs and for the authorities who evaluate projects. Because we have also found a positive relation between having patent expectations and the intensity of assistance, it 
can be cautiously argued that our results can, to some extent, inform us about the ability of public financiers to "pick the winners" in terms of future innovation activity (see, e.g., Cantner and Kösters 2012). That is, financiers may aim to favor the greatest number of potential projects with a high probability of innovation output, as successful projects may improve the records of the financiers and may in turn ensure performance pay.

In terms of regional policy, these results encourage regions to pay more attention to how expectations are met in their research and innovation (RIS3) strategies. The measurement challenges for expected and realized innovations should be seriously examined in regional funding programs. Novelty should be demonstrated not only at the company level but also at the regional and market levels when attempting to reach the ambitious goals of Europe 2020. The industry differences reveal that the projects in traditional sectors of the Finnish economy, for example, the forestry, wood, and bio industry, show a relatively higher likelihood of producing patents. On the one hand, this result may indicate that regions rely only on their old assets instead of generating new growth sectors, as emphasized in Europe 2020. On the other hand, new high technology start-ups tend not to rely on protecting ideas but instead on open sharing and the co-creation of innovation. Our results do not offer evidence regarding the impacts of collaboration in $R \& D$ as such or even for the desirability of private-led versus public-led R\&D. However, current Finnish innovation policy emphasizes that collaboration in R\&D should be led by the needs of the private sector in order to create commercial breakthroughs and regional growth. Thus, our results may provide marginal support for the current policy, because the patenting of private-led projects was more predictable for public financiers.

Further work needs to be undertaken to establish the extent to which these innovation expectations affect public funding decisions. The analysis in the current paper was conducted with a sample of subsidized projects only; to investigate the (causal) effects of expectations 
on funding decisions, a comparison (control) group of unsubsidized projects would be needed. However, measuring the public sector's expectations for innovation projects that never applied for funding is challenging.

We must stress the limitations of our analysis. Many of which relate to the data. Although we were able to measure innovation expectations in multiple ways, the data on realized outcomes were only on patenting. This is a weakness because historical evidence suggests that the majority of innovations occur outside of the patent system (Moser 2013). Hence, further research is needed to consider, for example, how innovation (and new production method) expectations are related to new innovations (and production methods). Another limitation of the analysis is that realized patenting was measured at the organizational level. Future research should aim to utilize project-level information on patent and innovation outcomes; recent developments in creating data sets on inventors and their networks (e.g., Li et al. 2014) are an interesting but challenging avenue for future research. Such data could also potentially provide opportunities to measure spillovers across partnering organizations and space more generally.

Our analysis has only addressed one set of innovation projects in Finland. For these projects, the public sector's innovation expectations were modest, and their goals may have been other than patenting. Therefore, external validation of the results is needed across programs that support innovation. More evidence is also required to validate the results across other countries, sample periods, and types of projects (incl. industries) (cf. Zúñiga-Vicente et al. 2014; see also Becker 2015).

The European Union's growth strategies are based on knowledge and innovation, which means large financial investments in research and development. We argue that policy makers should be aware of how well policy instruments meet the expectations that were placed on the project outcomes. Understanding the relationships among innovation 
expectations, subsidization, and patenting is beneficial to academic and policymaking communities alike, particularly in an era of shrinking public finance and increasing accountability for R\&D subsidies.

\section{REFERENCES}

Acs, Z.J., and D.B. Audretsch. 1987. Innovation, market structure, and firm size. Review of Economics and Statistics 69: 567-574. doi: 10.2307/1935950.

Acs, Z.J., and D.B. Audretsch. 1988. Innovation in large and small firms: An empirical analysis. American Economic Review 78: 678-690.

Acs, Z.J., and D.B. Audretsch. 1989. Patents as a measure of innovative activity. Kyklos 42: 171-180. doi: 10.1111/j.1467-6435.1989.tb00186.x.

Acs, Z.J., L. Anselin, and A. Varga. 2002. Patents and innovation counts as measures of regional production of new knowledge. Research Policy 31: 1069-1085. doi: 10.1016/S0048-7333(01)00184-6.

Alanen, A. 2005. Patenteilla mitaten olemme huipulla. Tietoaika - Economic Trends (4-5): 30-32 (in Finnish).

Artz, K.W., P.M. Norman, D.E. Hatfield, and L.B. Cardinal. 2010. A longitudinal study of the impact of R\&D, patents, and product innovation on Firm performance. Journal of Product Innovation Management 27: 725-740. doi: 10.1111/j.15405885.2010.00747.x.

Asheim, B.T., H.L. Smith, and C. Oughton. 2011. Regional innovation systems: theory, empirics and policy. Regional Studies 45: 875-891. doi: 10.1080/00343404.2011.596701.

Audretsch, D.B., and Z.J. Acs. 1991. Innovation and size at the firm level. Southern Economic Journal 57: 739-744. doi: 10.2307/1059787. 
Bacchiocchi, E., and F. Montobbio. 2009. Knowledge diffusion from university and public research. A comparison between US, Japan and Europe using patent citations. Journal of Technology Transfer 34: 169-181. doi: 10.1007/s10961-007-9070-y.

Basberg, B.L. 1987. Patents and the measurement of technological change: A survey of the literature. Research Policy 16: 131-41. doi: 10.1016/0048-7333(87)90027-8.

Becker, B. 2015. Public R\&D policies and private R\&D investment: A survey of the empirical evidence. Journal of Economic Surveys 29: 917-942. doi: 10.1111/joes.12074.

Bogner, W.C., and P. Bansal. 2007. Knowledge management as the basis of sustained high performance. Journal of Management Studies 44: 165-188. doi: 10.1111/j.14676486.2007.00667.x.

Buesa, M., J. Heijs, and T. Baumert. 2010. The determinants of regional innovation in Europe: A combined factorial and regression knowledge production function approach. Research Policy 39: 722-735. doi: 10.1016/j.respol.2010.02.016.

Cameron, A.C., and P.K. Trivedi. 2005. Microeconometrics: Methods and applications. New York, NY: Cambridge University Press.

Cantner, U., and S. Kösters. 2012. Picking the winner? Empirical evidence on the targeting of R\&D subsidies to start-ups. Small Business Economics 39: 921-936. doi: $10.1007 / \mathrm{s} 11187-011-9340-9$.

Canton, E., I. Grilo, J. Monteagudo, and P. van der Zwan. 2013. Perceived credit constraints in the European Union. Small Business Economics 41: 701-715. doi: 10.1007/s11187012-9451-y.

Cardinal, L.B., and D.E. Hatfield. 2000. Internal knowledge generation: The research laboratory and innovative productivity in the pharmaceutical industry. Journal of 
Engineering and Technology Management 17: 247-271. doi: 10.1016/S09234748(00)00025-4.

Cerulli, G. 2010. Modelling and measuring the effect of public subsidies on business R\&D: A critical review of the econometric literature. Economic Record 86: 421-449. doi: 10.1111/j.1475-4932.2009.00615.x.

Cohen, W.M., Nelson, R.R., and Walsh, J.P., 2000. Protecting their intellectual assets: appropriability conditions and why U.S. manufacturing firms patent (or not). National Bureau of Economic Research, Working Paper No. 7552.

Cohen-Blankshtain, G., and P. Nijkamp. 2004. The appreciative system of urban ICT policies: An analysis of perceptions of urban policy makers. Growth and Change 35: 166-197. doi: 10.1111/j.0017-4815.2004.00244.x.

Cohen-Blankshtain, G., P Nijkamp, and K. van Montfort. 2004. Modelling ICT perceptions and views of urban front-liners. Urban Studies 41: 2647-67. doi: 10.1080/0042098042000294600.

Cooke, P., M.G. Uranga, and G. Etxebarria. 1998. Regional systems of innovation: An evolutionary perspective. Environment and Planning A 30: 1563-1584. doi: 10.1068/a301563.

Crosby, M. 2000. Patents, innovation and growth. Economic Record 76: 255-262. doi: 10.1111/j.1475-4932.2000.tb00021.x.

Czarnitzki, D., K. Kraft, and S. Thorwarth. 2009. The knowledge production of 'R' and 'D.' Economics Letters 105: 141-143. doi: 10.1016/j.econlet.2009.06.020.

Edquist, C., M. Eriksson, and H. Sjögren. 2002. Characteristics of collaboration in product innovation in the regional system of innovation of East Gothia. European Planning Studies 10: 563-581. doi: 10.1080/09654310220145332. 
European Commission. 2010. Europe 2020: A Strategy for Smart, Sustainable and Inclusive Growth: Communication from the Commission. Brussels, Belgium: Publications Office.

Eurostat. 2016. Smarter, greener, more inclusive - Indicators to support the Europe 2020 strategy. 2016 edition. Luxembourg: Publications Office of the European Union. http://ec.europa.eu/eurostat/en/web/products-statistical-books/-/KS-EZ-16-001.

Finnish Patent and Registration Office. 2015. Patenttikäsikirja [Guidebook to patenting]. Helsinki, Finland: Finnish Patent and Registration Office (PRH). https://www.prh.fi/fi/asiakastiedotteet/2015/P_4187.html (in Finnish).

Finnish Patent and Registration Office. 2016. PRH - Domestic companies with the highest number of applications. Helsinki, Finland: Finnish Patent and Registration Office (PRH). https://www.prh.fi/en/patentit/Tilastoja/suurhakijat.html.

Fornahl, D., T. Broekel, and R. Boschma. 2011. What drives patent performance of German biotech firms? The impact of R\&D subsidies, knowledge networks and their location. Papers in Regional Science 90: 395-418. doi: 10.1111/j.1435-5957.2011.00361.x.

Fritsch, M., and G. Franke. 2004. Innovation, regional knowledge spillovers and R\&D cooperation. Research Policy 33: 245-255. doi: 10.1016/S0048-7333(03)00123-9.

Galasso, A., and T.S. Simcoe. 2011. CEO overconfidence and innovation. Management Science 57: 1469-1484. doi: 10.1287/mnsc.1110.1374.

Garcia-Quevedo, J. 2004. Do public subsidies complement business R\&D? A meta-analysis of the econometric evidence. Kyklos 57: 87-102. doi: 10.1111/j.00235962.2004.00244.x.

Gössling, T., and R. Rutten. 2007. Innovation in regions. European Planning Studies 15: 253270. doi: 10.1080/09654310601078788.

Greene, W.H. 2008. Econometric analysis, 6th ed. Upper Saddle River, NJ: Prentice Hall. 
Griliches, Z. 1990. Patent statistics as economic indicators: A survey. Journal of Economic Literature 28: 1661-1707.

Hall, B., A. Jaffe, and M. Trajtenberg. 2002. The NBER patent-citations data file: Lessons, insights, and methodological tools. In Patents, citations, and innovations: A window on the knowledge economy, ed. A.B. Jaffe and M. Trajtenberg, 403-460. Cambridge, MA: MIT Press.

Hall, B.H., Z. Griliches, and J.A. Hausman. 1983. Patents and R\&D: Searching for a lag structure. Working Paper 1227, National Bureau of Economic Research. http://www.nber.org/papers/w1227.

Ho, M.H.C. 2009. How regional innovation systems play a relative competitive role within knowledge networks. European Planning Studies 17: 1881-1905. doi: 10.1080/09654310903322389.

Lenihan, H. 2004. Evaluating Irish Industrial policy in terms of deadweight and displacement: A quantitative methodological approach. Applied Economics 36: 229-252. doi: $10.1080 / 0003684042000175343$.

Leydesdorff, L., and M. Meyer. 2006. Triple Helix indicators of knowledge-based innovation systems: Introduction to the Special issue. Research Policy 35: 1441-1449. doi: 10.1016/j.respol.2006.09.016.

Li, G.C., R. Lai, A. D’Amour, D.M. Doolin, Y. Sun, V.I. Torvik, A.Z. Yu, and L. Fleming. 2014. Disambiguation and co-authorship networks of the U.S. Patent Inventor Database (1975-2010). Research Policy 43: 941-55. doi: 10.1016/j.respol.2014.01.012.

Loikkanen, T., J. Konttinen, J. Hyvönen, L. Ruotsalainen, K. Tuominen, M. Waris, and V.P. Hyttinen. 2009. Acquisition, utilisation and the impact of patent and market information on innovation activities. VTT Tiedotteita - Research Notes 2484, VTT 
Technical Research Centre of Finland Research Notes 2484.

http://www.icsti.org/IMG/pdf/VTTImpactofPatent.pdf.

Lööf, H., and A. Broström. 2008. Does knowledge diffusion between university and industry increase innovativeness? Journal of Technology Transfer 33: 73-90. doi:

10.1007/s10961-006-9001-3.

Mansfield, E. 1986a. Patents and innovation: An empirical study. Management Science 32: 173-181. doi: 10.1287/mnsc.32.2.173.

Mansfield, E. 1986b. The R\&D tax credit and other technology policy issues. American Economic Review 76: 190-194.

Molle, W. 2007. European cohesion policy. London, UK: Routledge.

Moser, P. 2013. Patents and innovation: Evidence from economic history. Journal of Economic Perspectives 27: 23-44. doi: 10.1257/jep.27.1.23.

Nijkamp, P., R. Stough, and M.T. de Vaz. 2007. Local knowledge and innovation policy. Environment and Planning C: Government and Policy 25: 633-637. doi: $10.1068 / \mathrm{c} 2505 \mathrm{ed}$

Organisation for Economic Co-operation and Development (OECD). 2003. Polytechnic Education in Finland. Paris, France: OECD Publishing.

Organisation for Economic Co-operation and Development (OECD). 2005. OECD territorial reviews: Finland 2005. Paris, France: OECD Publishing.

Owen-Smith, J. 2003. From separate systems to a hybrid order: Accumulative advantage across public and private science at research one universities. Research Policy 32: 1081-1104. doi: 10.1016/S0048-7333(02)00111-7.

Park, S., and S. Lee. 2005. The national and regional innovation systems in Finland: From the path dependency to the path creation approach. AI \& Society 19: 180-195. doi: 10.1007/s00146-004-0305-2. 
Santamaría, L., A. Barge-Gil, and A. Modrego. 2010. Public selection and financing of R\&D cooperative projects: Credit versus subsidy funding. Research Policy 39: 549-563. doi: 10.1016/j.respol.2010.01.011.

Schmookler, J. 1966. Invention and economic growth. Cambridge, MA: Harvard University Press.

Schumpeter, J.A. 1934. The theory of economic development: An inquiry into profits, capital, credit, interest, and the business cycle. New Brunswick, NJ: Transaction Publishers. Sotarauta, M. 2012. Policy learning and the ‘cluster-flavoured innovation policy’ in Finland. Environment and Planning C: Government and Policy 30: 780-795. doi: 10.1068/c1191.

Statistics Finland. 2006. International patenting. http://www.stat.fi/til/pat/2006/pat_2006_2007-10-25_kat_003_en.html.

Swann, G.M.P. 2009. The economics of innovation: An introduction. Cheltenham, UK: Edward Elgar Publishing House.

Tanayama, T. 2007. Allocation and effects of R\&D subsidies: Selection, screening and strategic behavior. Acta Universitatis Oeconomicae Helsingiensis A-309. Helsinki, Finland: Helsinki School of Economics. https://aaltodoc.aalto.fi:443/handle/123456789/11509.

Taylor, C.T., A. Silberston, and Z.A. Silberston. 1973. The economic impact of the patent system: A study of the British experience. Cambridge, UK: Cambridge University Press.

Tekes. 2003. Alueiden elinvoima syntyy innovaatioista - Osaaminen, erikoistuminen ja verkottuminen ratkaisevat menestyksen kansainvälisessä kilpailussa. Markprint. http://www.tekes.fi/tekes/julkaisut1/alueiden-elinvoima-syntyy-innovaatioista-- 
osaaminen-erikoistuminen-ja-verkottuminen-ratkaisevat-menestyksenkansainvalisessa-kilpailussa/ (in Finnish).

Tekes. 2008. Innovaatiotoiminnan Vaikutukset: Osaamista, Uudistumista, Kasvua Ja Hyvinvointia 2008. https://www.tekes.fi/globalassets/julkaisut/ innovaatiotoiminnan_vaikutukset_2008.pdf (in Finnish).

Tekes. 2012. The impact of Tekes and innovation activities 2012. Markprint. http://www.tekes.fi/Julkaisut/tekes_and_innovation_activities_2012.pdf.

Tokila, A., and M. Haapanen. 2009. Evaluating project deadweight measures: Evidence from Finnish business subsidies. Environment and Planning C: Government and Policy 27: 124-40. doi: 10.1068/c0804b.

Tokila, A., M. Haapanen, and J. Ritsilä. 2008. Evaluation of investment subsidies: When is deadweight zero? International Review of Applied Economics 22: 585-600. doi: $10.1080 / 02692170802287631$.

Tokila, A., and M. Haapanen. 2012. Evaluation of deadweight spending in regional enterprise financing. Regional Studies 46: 185-201. doi: 10.1080/00343404.2010.497134.

Van Looy, B., J. Callaert, and K. Debackere. 2006. Publication and patent behavior of academic researchers: Conflicting, reinforcing or merely co-existing? Research Policy 35: 596-608. doi: 10.1016/j.respol.2006.02.003.

Veugelers, R., ed. 2009. The evaluation of the Finnish National Innovation System - Full report. The Research Institute of the Finnish Economy. http://econpapers.repec.org/bookchap/rifotbook/495.htm.

Vickers, G. 1965. The Art of judgment: A study of policy making. Thousand Oaks, CA: SAGE Publications.

Von Hippel, E. 1988. The sources of innovation. New York, NY: Oxford University Press. 
Yang, C., and H. Lin. 2012. Openness, absorptive capacity, and regional innovation in China.

Environment and Planning A 44: 333-355. doi: 10.1068/a44182.

Zúñiga-Vicente, J.Á., C. Alonso-Borrego, F.J. Forcadell, and J.I. Galán. 2014. Assessing the effect of public subsidies on firm R\&D investment: A survey. Journal of Economic Surveys 28: 36-67. doi:10.1111/j.1467-6419.2012.00738.x.

\section{APPENDIX}

TABle A1. ORDINARY LEAST SQUARES RESUltS ON THE INTENSITY OF AsSISTANCE.

\begin{tabular}{|c|c|c|c|c|c|c|}
\hline Variable & \multicolumn{2}{|c|}{ (1) Full sample } & \multicolumn{2}{|c|}{$\begin{array}{l}\text { (2) Private-led } \\
\text { projects }\end{array}$} & \multicolumn{2}{|c|}{$\begin{array}{l}\text { (3) Public-led } \\
\text { projects }\end{array}$} \\
\hline \multicolumn{7}{|l|}{$\begin{array}{l}\text { Project innovation } \\
\text { expectations }\end{array}$} \\
\hline Patent expectations & $0.027 * *$ & $(0.012)$ & $0.013 *$ & $(0.007)$ & $0.041 * *$ & $(0.017)$ \\
\hline Innovation expectations & -0.018 & $(0.014)$ & $0.018 * *$ & $(0.008)$ & -0.034 & $(0.024)$ \\
\hline $\begin{array}{l}\text { New production method } \\
\text { expectations }\end{array}$ & -0.018 & $(0.017)$ & $-0.021 * *$ & $(0.007)$ & -0.014 & $(0.027)$ \\
\hline Number of observations & \multicolumn{2}{|c|}{410} & \multicolumn{2}{|c|}{151} & \multicolumn{2}{|c|}{259} \\
\hline
\end{tabular}

$* \mathrm{p}<0.10 ; * * \mathrm{p}<0.05, * * * \mathrm{p}<0.01$.

Notes: Models also include all other explanatory variables that are used in Table 3; see also Table A2 in the Appendix. 
TABLE A2. DEFINITIONS OF EXPLANATORY VARIABLES.

\begin{tabular}{|c|c|}
\hline Variable & Definition \\
\hline \multicolumn{2}{|c|}{ Project innovation expectations } \\
\hline Patent expectations & $\begin{array}{l}1 \text { if Tekes experts expect that the project will generate at least one new } \\
\text { patent; } 0 \text { if no patents are expected. }\end{array}$ \\
\hline $\begin{array}{l}\text { Innovation } \\
\text { expectations }\end{array}$ & $\begin{array}{l}1 \text { if Tekes experts expect that the project will generate at least one new } \\
\text { innovation; } 0 \text { if no innovations are expected. }\end{array}$ \\
\hline $\begin{array}{l}\text { Expecting new } \\
\text { production methods }\end{array}$ & $\begin{array}{l}1 \text { if Tekes experts expect that the project will generate at least one new } \\
\text { production method; } 0 \text { if no new production methods are expected. }\end{array}$ \\
\hline \multicolumn{2}{|c|}{ Other project characteristics } \\
\hline Project costs & $\begin{array}{l}\text { Total project costs (i.e., purchasing cost of fixed assets) as estimated by } \\
\text { the firm in its subsidy application }(€ 100000) \text {. }\end{array}$ \\
\hline Intensity of assistance & Ratio of public subsidy to project costs. \\
\hline Zero deadweight & $\begin{array}{l}1 \text { if Tekes experts estimate that the project would have been abandoned in } \\
\text { the absence of subsidy; } 0 \text { otherwise. }\end{array}$ \\
\hline ICT & $\begin{array}{l}1 \text { if project type is information and communications technology (ICT) } \\
\text { and learning; } 0 \text { otherwise (reference). }\end{array}$ \\
\hline Pharmaceutical & 1 if project type is pharmaceutical industry; 0 otherwise. \\
\hline Forestry & $\begin{array}{l}1 \text { if project type is forestry, wood and bio industry, renewable; } 0 \\
\text { otherwise. }\end{array}$ \\
\hline Metal & 1 if project type is metal and technology industry; 0 otherwise. \\
\hline Other industry & $\begin{array}{l}1 \text { if project type is product innovation in some other industry (e.g., food, } \\
\text { chemistry, textile, and health industry); } 0 \text { otherwise. }\end{array}$ \\
\hline $\begin{array}{l}\text { Develop operating } \\
\text { environment }\end{array}$ & $\begin{array}{l}1 \text { if project type is development of operating environment for business } \\
\text { networks; } 0 \text { otherwise. }\end{array}$ \\
\hline \multicolumn{2}{|c|}{ Characteristics of lead organization } \\
\hline Small & 1 if organization employs $1-49$ people; 0 otherwise (ref.). \\
\hline Medium & 1 if organization employs $50-249$ people; 0 otherwise. \\
\hline Large & 1 if organization employs at least 250 people; 0 otherwise. \\
\hline Public & $\begin{array}{l}1 \text { if project is led by public sector organization (e.g., university, } \\
\text { polytechnic unit, local development organization, independent public } \\
\text { research center); } 0 \text { if led by private firm. }\end{array}$ \\
\hline University & 1 if university unit; 0 otherwise (ref.). \\
\hline Polytechnic & 1 if polytechnic unit or local development organization; 0 otherwise. \\
\hline Research center & 1 if independent public research center; 0 otherwise. \\
\hline Turnover of firm & Annual turnover of private firm ( $€$ millions). \\
\hline Patent before & $\begin{array}{l}1 \text { if organization had at least one patent before public grant application } \\
\text { was approved; } 0 \text { otherwise. }\end{array}$ \\
\hline \multicolumn{2}{|r|}{20} \\
\hline 2000 & 1 if project was granted funding in $2000 ; 0$ otherwise (ref.). \\
\hline 2001 & 1 if project was granted funding in $2001 ; 0$ otherwise. \\
\hline 2002 & 1 if project was granted funding in $2002 ; 0$ otherwise. \\
\hline 2003 & 1 if project was granted funding in $2003 ; 0$ otherwise. \\
\hline 2004 & 1 if project was granted funding in 2004; 0 otherwise. \\
\hline \multicolumn{2}{|r|}{ - } \\
\hline South & 1 if project is in Southern Finland (NUTS2); 0 otherwise (ref.). \\
\hline West & 1 if project is in Western Finland (NUTS2); 0 otherwise. \\
\hline East & 1 if project is in Eastern Finland (NUTS2); 0 otherwise. \\
\hline North & 1 if project is in Northern Finland (NUTS2); 0 otherwise. \\
\hline
\end{tabular}




\section{NOTES}

${ }^{1}$ Swann (2009) introduces five basic approaches to gathering data and measuring innovation: 1) describing innovations in detail (such as technical characteristics, e.g., processor speed for computer data), 2) counting innovations based on expert monitoring, 3) questionnaire surveys of innovative companies, 4) counting the number of patents issued, and 5) using R\&D input data.

${ }^{2}$ See also Vickers' (1965) theory on the mental process of decision-making.

${ }^{3}$ Firms' perceptions were also studied by Canton et al. (2012), who found that the youngest and smallest SMEs had the worst perceptions of access to bank loans.

${ }^{4}$ See Garcia-Quevedo (2004) for a meta-analysis and Zúñiga-Vicente et al. (2014) and Becker (2015) for recent surveys of the estimated effects of public subsidies on private R\&D and innovation. Recently, more evidence has been based on causal methods (see Cerulli 2010), which utilize information on both realized and counterfactual outcomes (such as private R\&D expenditures, profitability or patents) for subsidized and unsubsidized firms.

${ }^{5}$ See Park and Lee (2005), Veugelers (2009), and Sotarauta (2012) for more information on the Finnish innovation system.

${ }^{6}$ The other two are product innovation and production method/process innovation.

${ }^{7}$ A well-developed triple helix model has been considered a strength of Finnish innovation policy (Organisation for Economic Co-operation and Development [OECD] 2005).

${ }^{8}$ Consistent with recent evidence on R\&D subsidies (see Becker 2015), we assume additionality effects from a subsidy (instead of full crowding-out); that is, subsidies do not completely replace private investments in $\mathrm{R} \& \mathrm{D}$. 
${ }^{9}$ See Swann (2009) for alternative approaches to measuring innovation. Unfortunately, our data do not contain information on whether the projects eventually led to innovations or new production methods (other than patents).

${ }^{10}$ In monetary terms, $32.3 \%$ of the funding was granted to projects led by private firms and $67.7 \%$ to projects led by public organizations.

${ }^{11}$ We utilize a lengthy ten-year follow-up period because the time to receiving a patent is up to eight years in the data (for the small subsample of projects for which we can identify this information). Our main results, reported below, are robust to utilizing a five-year follow-up period instead of a ten-year period.

${ }^{12}$ On average, $20 \%$ of innovative firms held at least one patent in Finland in 2000. For noninnovative firms, this figure was 2\% (Alanen 2005).

${ }^{13}$ In practice, it is impossible to measure patenting at the project level because the project descriptions are often very incomplete in the data.

${ }^{14}$ Overall, the public financiers expect patents, innovations, or new production methods from $41 \%$ of the projects.

${ }^{15}$ We have also calculated marginal effects at mean values (MEMs). Both types of marginal effects produce qualitatively similar results.

${ }^{16}$ An insignificant public dummy in column (1) of Table 3 implies that private-led and public-led projects are equally likely to be granted a patent, ceteris paribus.

17 Additional multivariate analyses utilizing the full sample show that the innovation expectations and new production methods expectations variables remain significant in all models, when we gradually remove all other variables (including patent expectations) from the model. The variable describing patent expectations is insignificant in all specifications. These estimation results are available from the authors on request. 